УДК 581.143:577.175.1.05

doi: $10.25128 / 2078-2357.19 .2 .15$

С. О. ПРИПЛАВКО, В. М. ГАВІЙ

Ніжинський державний університет імені Миколи Гоголя

вул. Графська, 2, Ніжин, Чернігівська область

e-mail: gaviyv@gmail.com

\title{
ПОРІВНЯЛЬНИЙ ВПЛИВ РЕГУЛЯТОРІВ РОСТУ АЗОТОФІТ, ЯНТАРНА КИСЛОТА ТА ВИМПЕЛ НА ДИНАМІКУ ПРОЦЕСІВ РОСТУ ТА ПРОДУКТИВНІСТЬ ОЗИМОЇ ПШЕНИЦІ СОРТУ ЮВІВАТА
}

У статті наведені результати вивчення впливу регуляторів росту рослин Азотофіт, Янтарна кислота та Вимпел на польову схожість насіння, динаміку показників росту (середня висота рослин та довжина кореня, маса сирої та сухої речовини, відсоток сухої речовини в рослинній пробі) та елементи продуктивності (довжина складного колоса, кількість зернин та маса складного колоса) озимої пшениці сорту Ювівата.

Ключові слова: регулятори росту рослин, озима пшениия, схожість насіння, висота рослин, довжина кореня, маса сирої речовини, маса сухої речовини, приріст, продуктивність.

Вступ. Серед найважливіших зернових культур озима пшениця за посівними площами займає в Україні перше місце. Вона $є$ головною продовольчою культурою, яка за врожайністю та валовим збором продовольчого зерна займає провідну роль у формуванні високоефективного продовольчого комплексу нашої держави.

У технологіях вирощування озимої пшениці залишається багато невирішених питань, серед яких: скорочення тривалості вегетаційного періоду, підвищення стійкості до несприятливих умов навколишнього середовища, зменшення накопичення шкідливих речовин, а також збільшення врожайності та якості отриманої продукції.

Дослідження багатьох учених свідчать про те, що технології вирощування озимої пшениці, подібно до інших культур, можна успішно регулювати за допомогою регуляторів росту рослин. Ці речовини мають комплексний вплив на ріст і розвиток, зосереджують свою дію у рослинних клітинах, регулюючи баланс фітогормонів, що веде до стимулювання ростових процесів $[1,2]$. До складу речовин входять біохімічні сполуки, які регулюють взаємодію між клітинами, тканинами, органами і в мікрокількостях необхідні для запуску та послідовного регулювання фізіологічних і морфогенетичних програм росту та розвитку рослини $[3,4]$. Сучасні регулятори росту розроблені на основі найновіших наукових досягнень в галузі хімії та біології. Вони $є$ високоефективними через здатність шляхом оптимізації проходження в рослинах фізіолого-біохімічних процесів підвищувати врожаї сільськогосподарських культур [5].

Регулятори росту рослин можуть використовуватись як для передпосівної обробки насіння, так і для обприскування рослин під час вегетації. Їх застосування для обробки насіння перед висіванням дозволяє підвищити схожість насіння, адаптуватись проросткам до не завжди сприятливих умов зростання за рахунок активізації обмінних процесів. Це, у свою чергу, забезпечує покращення процесів росту рослин та підвищує їх врожайність [2].

Мета дослідження - вивчення впливу регуляторів росту рослин Азотофіт, Янтарна кислота та Вимпел на динаміку процесів росту та продуктивність озимої пшениці сорту Ювівата.

\section{Матеріал і методи досліджень}

Визначення динаміки показників росту та продуктивності дає змогу прослідкувати за впливом регуляторів росту, якими обробляли насіння перед висівом, та встановити їх ефективність на всіх етапах розвитку рослин. Для цього були проведені трирічні польові дослідження 3 використанням регуляторів росту рослин Азотофіту, Янтарної кислоти та Вимпелу. Насіння 
озимої пшениці сорту Ювівата обробляли розчинами цих препаратів згідно інструкцій по застосуванню. Площа дослідної ділянки становила $40 \mathrm{~m}^{2}$. Для проведення досліджень використовували польовий метод - для з'ясування ефективності передпосівної обробки насіння озимої пшениці на динаміку ростових процесів та продуктивність цієї культури; лабораторний - для визначення кількісних і якісних змін у рослинах; статистичний - для визначення на основі дисперсійного та кореляційного аналізів достовірності одержаних досліджень.

\section{Результати досліджень та їх обговорення}

Отримані дані свідчать, що польова схожість у контролі становила в середньому $85 \%$, тоді як в дослідних варіантах вона коливається від 74,3\% до 83,3\%. Найменшою вона була у варіанті, де застосовували Янтарну кислоту. 3'ясовано, що регулятори росту не впливають на показник польової схожості рослин, однак відсоток схожості був досить високий як у контрольному, так і у дослідних варіантах. Це можна пояснити тим, що висівання насіння проводили в оптимальні строки за оптимальних погодних умов. При цьому кількість власних фітогормонів у проростаючому насінні була достатньою.

За результатами визначення середніх значень висоти рослин та довжини коренів (табл. 1) було встановлено, що після першого вимірювання середньої висоти рослин озимої пшениці у осінній період найкращий вплив виявив препарат Вимпел. Його показники перевищували контрольний варіант на $3,4 \%$. Найгірший результат спостерігався у варіанті, обробленому Янтарною кислотою і був менший від контролю на 2,5\%. Після другого вимірювання висота рослин зросла в усіх варіантах на 3,1-4,3 см. Максимальна висота залишалась у варіанті із застосуванням Вимпелу, а найменша - у варіанті з Янтарною кислотою.

Таблиия 1

Вплив регуляторів росту на середні значення висоти рослин та довжини коренів озимої пшениці

\begin{tabular}{|c|c|c|c|c|c|c|c|c|}
\hline \multirow[b]{2}{*}{ Варіант } & \multicolumn{2}{|c|}{$\begin{array}{c}1 \text { вимірювання } \\
\text { I декада жовтня }\end{array}$} & \multicolumn{2}{|c|}{$\begin{array}{c}2 \text { вимірювання } \\
\text { I декада листопада }\end{array}$} & \multicolumn{2}{|c|}{$\begin{array}{l}3 \text { вимірювання } \\
\text { I декада квітня }\end{array}$} & \multicolumn{2}{|c|}{$\begin{array}{l}4 \text { вимірювання } \\
\text { I декада травня }\end{array}$} \\
\hline & 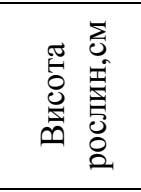 & 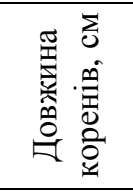 & 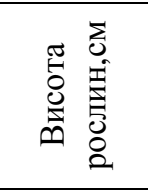 & 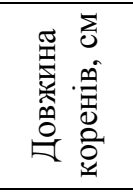 & 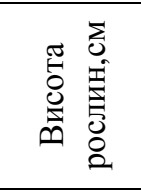 & 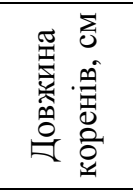 & 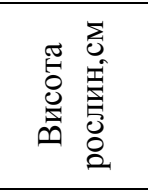 & 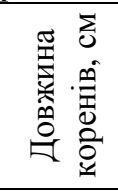 \\
\hline Контроль & $11,9 \pm 0,1$ & $5,9 \pm 0,1$ & $16,2 \pm 0,3$ & $6,5 \pm 0,2$ & $16,7 \pm 0,3$ & $6,6 \pm 0,2$ & $50,1 \pm 0,6$ & $7,3 \pm 0,4$ \\
\hline Азотофіт & $11,8 \pm 0,1$ & $5,9 \pm 0,1$ & $15,0 \pm 0,5$ & $6,2 \pm 0,2$ & $15,5 \pm 0,5$ & $7,4 \pm 0,4$ & $48,9 \pm 0,5$ & $8,1 \pm 0,5$ \\
\hline Вимпел & $12,3 \pm 0,3$ & $6,0 \pm 0,1$ & $16,2 \pm 0,4$ & $7,7 \pm 0,6$ & $16,3 \pm 0,4$ & $7,8 \pm 0,3$ & $49,3 \pm 0,7$ & $8,7 \pm 0,4$ \\
\hline $\begin{array}{r}\text { Янтарна } \\
\text { кислота }\end{array}$ & $11,6 \pm 0,2$ & $5,4 \pm 0,3$ & $14,7 \pm 0,3$ & $7,5 \pm 0,4$ & $15,5 \pm 0,3$ & $8,0 \pm 0,1$ & $45,2 \pm 0,9$ & $9,2 \pm 0,6$ \\
\hline
\end{tabular}

Доцільність дослідження визначення висоти рослин озимої пшениці у весняний період зумовлена тим, що високі рослини схильні до вилягання, що у подальшому може негативно вплинути на обсяги отриманого продовольчого зерна. Аналіз даних свідчить про те, що під час третього (весняного) вимірювання найвищими рослини були в контрольному варіанті. Одночасно з тим, найменша висота спостерігалась у варіантах, де було здійснено передпосівну обробку насіння Азотофітом і Янтарною кислотою. Обробка препаратом Вимпел на даний показник ефективності не виявила.

Четверте вимірювання показало, що найефективніший вплив на озиму пшеницю за цим показником здійснила Янтарна кислота. Ця сполука значно загальмувала ріст рослин у порівнянні з іншими регуляторами росту та 3 контролем. Так, середнє значення варіанта було нижчим за контрольний на 4,9 см (на $10 \%)$.

Відомо, що коренева система не лише закріплює рослину в грунті, а й забезпечує надходження в рослину необхідних поживних речовин. Тому довжина коренів є важливим показником росту рослин. Після вимірювань середньої довжини коренів у рослин озимої пшениці у осінній період найкращий показник спостерігався у варіанті із застосуванням Вимпелу, а найгірший - із Янтарною кислотою. Приріст середньої довжини коренів у осінній 92 ISSN 2078-2357. Наук. зап. Терноп. нац. пед. ун-ту. Сер. Біол., 2019, № 2 (76) 
період коливався в межах 0,3-2,1 см. Причому максимальним він був у варіанті, обробленому Янтарною кислотою. Обробка даних, отриманих після третього та четвертого весняних вимірювань, показала, що більшу дію на ріст кореневої системи у весняний період виявила Янтарна кислота. Після третього вимірювання корені рослин у варіанті, обробленому цією сполукою, перевищували середню довжину контрольного варіанта на 21,2\%.

Після четвертого вимірювання довжина коренів у варіанті з обробкою Янтарною кислотою збільшилась і перевищила контроль на 26\%. Середня довжина коренів рослин у контролі залишалася найменшою протягом весняних вимірювань.

Отже, досліджувані регулятори росту рослин здійснюють позитивний вплив на процеси розвитку коренів рослин озимої пшениці у осінній та весняний періоди. Ця особливість забезпечить можливість кращого живлення рослин необхідними елементами.

Сира речовина рослини представлена в основному водою, яка належить до найбільш важливих факторів життя. У зеленій масі злакових, бобових та інших культур їі частка значна 75-85\%. Рівень ії вмісту визначає направленість та інтенсивність всіх фізіолого-біохімічних процесів [6].

Після першого зважування показники дії синтетичних регуляторів на масу сирої речовини рослин озимої пшениці близькі до контролю. Після другого зважування найкращі результати було отримано при застосуванні препарату Вимпел, які перевищили контроль на $21 \%$ (табл. 2). Дещо слабшу дію виявив Азотофіт.

Після другого вимірювання найбільший приріст маси сирої речовини спостерігався у варіанті із застосуванням Вимпелу. Янтарна кислота й Азотофіт виявили слабшу дію.

Таблиия 2

Вплив регуляторів росту на масу сирої та сухої речовини рослин озимої пшениці

\begin{tabular}{|c|c|c|c|c|c|c|c|c|}
\hline \multirow[b]{2}{*}{ Варіант } & \multicolumn{2}{|c|}{$\begin{array}{c}1 \text { зважування } \\
\text { I декада жовтня }\end{array}$} & \multicolumn{2}{|c|}{$\begin{array}{c}2 \text { зважування } \\
\text { I декада листопада }\end{array}$} & \multicolumn{2}{|c|}{$\begin{array}{c}3 \text { зважування } \\
\text { I декада квітня }\end{array}$} & \multicolumn{2}{|c|}{$\begin{array}{c}4 \text { зважування } \\
\text { I декада травня }\end{array}$} \\
\hline & 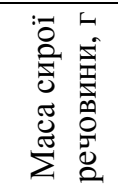 & 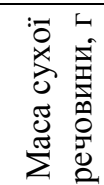 & 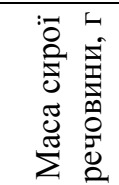 & 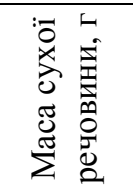 & 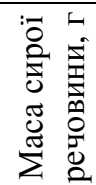 & 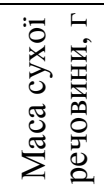 & 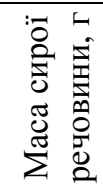 & 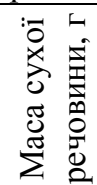 \\
\hline Контроль & $\begin{array}{c}1,07 \\
\pm 0,01 \\
\end{array}$ & $\begin{array}{c}0,33 \\
\pm 0,01 \\
\end{array}$ & $\begin{array}{c}1,25 \\
\pm 0,05 \\
\end{array}$ & $\begin{array}{c}0,63 \\
\pm 0,01 \\
\end{array}$ & $\begin{array}{c}6,0 \\
\pm 0,2 \\
\end{array}$ & $\begin{array}{c}1,5 \\
\pm 0,1 \\
\end{array}$ & $\begin{array}{l}71,3 \\
\pm 5 \\
\end{array}$ & $\begin{array}{c}32,0 \\
\pm 4 \\
\end{array}$ \\
\hline Азотофіт & $\begin{array}{c}1,09 \\
\pm 0,01 \\
\end{array}$ & $\begin{array}{c}0,33 \\
\pm 0,01 \\
\end{array}$ & $\begin{array}{c}1,41 \\
\pm 0,07 \\
\end{array}$ & $\begin{array}{c}0,64 \\
\pm 0,02 \\
\end{array}$ & $\begin{array}{c}6,3 \\
\pm 0,1 \\
\end{array}$ & $\begin{array}{r}1,6 \\
\pm 0,1 \\
\end{array}$ & $\begin{array}{c}152,0 \\
\pm 8\end{array}$ & $\begin{array}{c}65,0 \\
\pm 6 \\
\end{array}$ \\
\hline Вимпел & $\begin{array}{c}1,02 \\
\pm 0,03\end{array}$ & $\begin{array}{c}0,31 \\
\pm 0,02\end{array}$ & $\begin{array}{c}1,51 \\
\pm 0,09\end{array}$ & $\begin{array}{c}0,61 \\
\pm 0,01\end{array}$ & $\begin{array}{c}6,3 \\
\pm 0,1\end{array}$ & $\begin{array}{c}1,8 \\
\pm 0,2\end{array}$ & $\begin{array}{l}76,0 \\
\pm 4\end{array}$ & $\begin{array}{c}27,0 \\
\pm 3\end{array}$ \\
\hline Янтарна кислота & $\begin{array}{c}1,00 \\
\pm 0,02\end{array}$ & $\begin{array}{c}0,32 \\
\pm 0,01\end{array}$ & $\begin{array}{c}1,30 \\
\pm 0,04\end{array}$ & $\begin{array}{c}0,65 \\
\pm 0,02\end{array}$ & $\begin{array}{r}7,0 \\
\pm 0,4\end{array}$ & $\begin{array}{c}1,8 \\
\pm 0,1\end{array}$ & $\begin{array}{c}139,3 \\
\pm 7\end{array}$ & $\begin{array}{c}59,6 \\
\pm 5\end{array}$ \\
\hline
\end{tabular}

Зважування рослин, яке проводилось у весняний період, показало, що найкращі результати було отримано при застосуванні препарату Янтарна кислота, які перевищили показники контролю на 16\%. Інші регулятори росту виявили слабшу дію. Після останнього зважування найкращий вплив на масу сирої речовини рослин виявив Азотофіт, значення якого перевищило показник контролю на $113 \%$. Дещо меншою маса була у рослин, які пройшли передпосівну обробку Янтарною кислотою (але на 95\% більша за контроль).

У ході проведення останнього дослідження за цим показником було встановлено його приріст у весняний період. Накопичення маси сирої речовини відбувалось набагато активніше у порівнянні з осіннім. Маса сирої речовини зросла у всіх варіантах на 65,3-145,7 г. Причому особливо швидкими темпами збільшення маси сирої речовини відбувалось у рослинах, оброблених перед висіванням розчином Азотофіту. Він виявив найефективніший вплив, приріст маси сирої речовини перевищив показники контролю більше ніж у 2,2 рази.

Кількість сухої речовини у рослині відображає вміст органічних і мінеральних речовин та деяких хімічних елементів. У складі сухої речовини рослин 90-95\% становлять органічні 
сполуки, які представлені білками та іншими азотистими сполуками, жирами, крохмалем, цукрами, клітковиною, пектинами. Дослідження цього показника дає змогу визначити вплив регуляторів росту на інтенсивність живлення рослин (засвоєння води, азоту, зольних елементів та мінеральних добрив) [7].

Маса сухої речовини після першого зважування (табл. 2) коливалась у всіх варіантах від 0,31 до 0,33 г. Більшою вона була у контролі та у варіанті, обробленому Азотофітом.

Результати, отримані після другого зважування, показали зростання маси сухої речовини у рослин усіх варіантів, однак найвищими вони були у рослин варіанта, насіння якого було оброблене Янтарною кислотою. Це можна пояснити тим, що зазначена сполука покращує засвоєння рослиною поживних речовин та $є$ стресовим адаптогеном. Дещо гірше, але позитивно, проявив себе Азотофіт.

Після третього зважування суха маса рослин коливалась у межах 1,5-1,8 г. Найбільші показники спостерігались у рослин, оброблених Вимпелом і Янтарною кислотою, які перевищили показники контролю на $20 \%$.

Четверте зважування показало, що найкращий вплив на масу сухої речовини виявив Азотофіт, який сприяв збільшенню цього показника у 2 рази порівняно з контрольним. Янтарна кислота при застосуванні іiі для передпосівної обробки насіння сприяла перевищенню значення контролю у 1,8 рази.

За період досліджень найбільш ефективний вплив на приріст маси сухої речовини виявили Азотофіт і Янтарна кислота, оскільки їх показники перевищували контроль під час усіх зважувань.

Процентний вміст сухої речовини представляє собою відсоткове співвідношення між масою сухої і сирої речовини в рослині. Чим більший відсоток сухої речовини, тим краще рослини переживають несприятливі періоди, які можуть бути пов'язані з нестачею води чи відсутністю оптимальних температур. Це пояснюється тим, що при розщепленні органічних речовин, що входять до складу сухої речовини рослини, утворюється значна кількість енергії, яка необхідна для життєдіяльності рослин.

Відповідно до таблиці 3, перші розрахунки показали, що відсоток сухої речовини був у межах 30,2-31,9\%. При цьому найбільшим він був у рослин, насіння якого було оброблене Янтарною кислотою. По відношенню до рослин, насіння яких не обробляли препаратами, цей показник був більшим на $4 \%$.

Таблиия 3

Вплив регуляторів росту на відсоток сухої речовини у рослинній пробі озимої пшениці

\begin{tabular}{|c|c|c|c|c|c|c|c|c|}
\hline \multirow[b]{3}{*}{ Варіант } & \multicolumn{8}{|c|}{ Відсоток сухої речовини в рослинній пробі, \% } \\
\hline & \multicolumn{2}{|c|}{$\begin{array}{c}1 \text { зважування } \\
\text { I декада жовтня }\end{array}$} & \multicolumn{2}{|c|}{$\begin{array}{c}2 \text { зважування } \\
\text { I декада листопад }\end{array}$} & \multicolumn{2}{|c|}{$\begin{array}{c}3 \text { зважування } \\
\text { I декада квітня }\end{array}$} & \multicolumn{2}{|c|}{$\begin{array}{c}4 \text { зважування } \\
\text { I декада травня }\end{array}$} \\
\hline & bo & 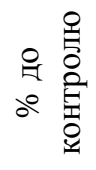 & o & 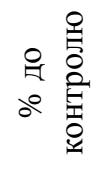 & so & 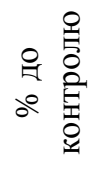 & o & 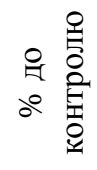 \\
\hline Азотофіт & $30,2 \pm 0,1$ & 98 & $45,6 \pm 0,4$ & 89 & $25,4 \pm 0,3$ & 102 & $42,8 \pm 0,4$ & 96 \\
\hline Вимпел & $30,6 \pm 0,2$ & 99 & $41,0 \pm 0,5$ & 80 & $28,6 \pm 0,7$ & 114 & $49,0 \pm 0,9$ & 109 \\
\hline Янтарна кислота & $31,9 \pm 0,4$ & 104 & $50,2 \pm 0,8$ & 98 & $25,7 \pm 0,8$ & 103 & $42,8 \pm 0,8$ & 96 \\
\hline Контроль & $30,7 \pm 0,2$ & 100 & $51,0 \pm 0,6$ & 100 & $25,0 \pm 0,9$ & 100 & $44,8 \pm 0,7$ & 100 \\
\hline
\end{tabular}

Після другого зважування значення досліджуваного показника змінилось у бік зростання, що свідчить про накопичення в рослинах сухої речовини. Воно коливалось у межах 41-51\%. При цьому було встановлено, що регулятори росту не виявили позитивної дії по відношенню до контролю. 
Третє зважування показало, що всі регулятори росту виявили на цей показник позитивний вплив. Відсоток сухої речовини в рослинній пробі перевищував контроль на 2$14 \%$. Найбільш ефективним за цим показником виявився препарат Вимпел.

Останнє зважування показало, що показники у всіх варіантах зросли. Однак позитивний вплив препаратів дещо знизився. Ефективну дію виявив лише Вимпел, під впливом якого відсоток сухої речовини в рослинній пробі був більший на 9 одиниць у порівнянні до контролю. Це можна пояснити наявністю в складі Вимпелу полімерів ПЕГ 400 і ПЕГ 1500 та гумату натрію. Завдяки першим здійснюється структурування вільної внутрішньоклітинної води, покращуючи іiі біологічну активність, прискорюються процеси фотосинтезу, транспірації та інтенсивність мінерального живлення; завдяки другому відбувається поліпшення живлення, що супроводжується активізацією росту надземної частини рослин $[8,9]$.

Застосування синтетичних регуляторів росту суттєво впливає на продуктивність озимої пшениці, а саме на довжину складного колоса, кількість зернин та масу складного колоса (табл. 4).

Дослідження показали, що найбільшу ефективність виявив Азотофіт, який збільшив довжину складного колоса озимої пшениці на $21,1 \%$ порівняно 3 контролем. Збільшення довжини складного колоса під впливом Вимпелу відбулося на 17,6\%.

Таблиия 4

Вплив синтетичних регуляторів росту на елементи структури врожаю озимої пшениці

\begin{tabular}{|c|c|c|c|c|c|c|}
\hline \multirow[b]{2}{*}{ Варіант } & \multicolumn{6}{|c|}{ Елементи структури врожаю озимої пшениці } \\
\hline & 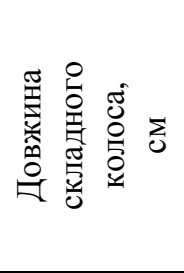 & 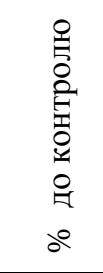 & 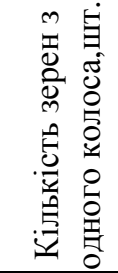 & 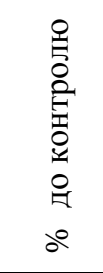 & 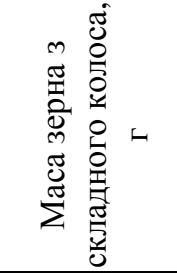 & 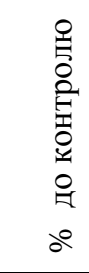 \\
\hline Контроль & $7,81 \pm 0,19$ & 100 & $32 \pm 1,4$ & 100 & $1,64 \pm 0,15$ & 100 \\
\hline $\begin{array}{c}\text { Янтарна } \\
\text { кислота }\end{array}$ & $8,8 \pm 0,14$ & 112,1 & $37 \pm 1,5$ & 115,6 & $1,78 \pm 0,19$ & 118,0 \\
\hline Вимпел & $9,2 \pm 0,15$ & 117,6 & $43 \pm 1,4$ & 134,4 & $2,102 \pm 0,13$ & 131,7 \\
\hline Азотофіт & $9,4 \pm 0,13$ & 121,1 & $49 \pm 1,5$ & 153,1 & $2,382 \pm 0,14$ & 150,1 \\
\hline
\end{tabular}

Застосування синтетичних регуляторів росту значною мірою вплинуло на зернову продуктивність озимої пшениці сорту Ювівата. Так, під впливом Вимпелу кількість зерен у складному колосі збільшилася на $34,4 \%$, Янтарної кислоти - на $15,6 \%$ та під впливом Азотофіту - на 53,1\% порівняно з контролем. Під впливом Янтарної кислоти маса зерна із складного колоса збільшилася на $18 \%$, Вимпелу - на 31,7\%, під впливом Азотофіту - на 50,1\% порівняно до контролю. Найвища врожайність озимої пшениці спостерігалася при обробці насіння Азотофітом і складала 56,2 ц/га.

\section{Висновки}

Отже, за результатами досліджень було встановлено, що регулятори росту рослин Азотофіт, Янтарна кислота та Вимпел ефективно впливають на процеси росту та продуктивність рослин озимої пшениці сорту Ювівата. Їх застосування на посівах озимої пшениці можна здійснювати для обробки насіння перед сівбою. Визначення найбільшої ефективності кожного окремо взятого регулятора, а також можливість їх поєднання для покращення процесів росту рослин потребує подальшого дослідження.

1. Біологічні основи інтегрованої дії гербіцидів і регуляторів росту рослин / В. П. Карпенко, 3. М. Грицаєнко, Р. М. Притуляк та ін.; за ред. В. П. Карпенка. Умань: Видавець «Сочінський», $1012.357 \mathrm{c}$.

2. Деева В. П. Регуляторы роста растений: Механизмы действия и использование в агротехнологиях. Минск: Наука, 2008. 86 с.

ISSN 2078-2357. Наук. зап. Терноп. нац. пед. ун-ту. Сер. Біол., 2019, № 2 (76) 
3. Калінін Л. Ф. Застосування регуляторів росту в сільському господарстві. К.: Урожай, 1989. 168 с.

4. Педоренко І. Ю., Баланда О. В. Природні біостимулятори росту та розвитку сільськогосподарських культур. «Молодь у вирішенні екологічних та соиіально-економічних проблем сьогодення»: матеріали Міжн. конф. Кам’янець-Подільськ, 2012. С. 63-64.

5. Ponomarenko S. P., Hrytsaenko Z. M., Tsygankova V. A. Increase of Plant Resistance to Diseases, Pests and Stresses with New Biostimulants. Proceedings of the I st world congress on the USE of Biostimulants in Agriculture. Eds.: S. Saa Silva [et al.]. Acta Horticulturae 1009, 2013. P. 225-234.

6. Григорюк І. П. Реакція рослин на водний і температурний стреси та способи їх регуляції: автореф. дис. ...канд. с-г наук: 03.00.12. Київ, 1996. 20 с.

7. Господаренко Г. М. Агрохімія. Умань: ВІЗАВІ, 2014. 400 с.

8. Шуляк И. В., Грушова Е. И., Семенченко А. М. Реологические свойства водных растворов полиэтиленгликолей различной молекулярной массы. Журнал физической химии. 2011. Т. 85. № 3. С. 485-488.

9. Кондратенко Е. П., Сухих А. С., Вербицкая Н. В., Соболева О.М. Биостимулирующие и физикохимические свойства гумата натрия. Химия растительного сырья. 2016. № 3. Режим доступа: jornal.asu.ru/ index.php/cw/article/view/1185

\section{References}

1. Biolohichni osnovy intehrovanoyi diyi herbitsydiv i rehulyatoriv rostu roslyn / V. P. Karpenko, Z. M. Hrytsaenko, R. M. Prytulyak ta in. za red. V. P. Karpenka.; Uman’: Vydavets' «Sochins'kyy», 1012. 357 s. (in Ukrainian).

2. Deeva V. P. Rehulyatory rosta rastenyy: Mekhanyzmy deystvyya y yspol'zovanye v ahrotekhnolohyyakh. Mynsk: Nauka, 2008. 86 s. (in Belarus).

3. Kalinin L. F. Zastosuvannya rehulyatoriv rostu v sil's'komu hospodarstvi. K.: Urozhay, 1989. 168 s. (in Ukrainian).

4. Pedorenko I. YU., Balanda O. V. Pryrodni biostymulyatory rostu ta rozvytku sil's'kohospodars'kykh kul'tur. «Molod' u vyrishenni ekolohichnykh ta sotsial'no-ekonomichnykh problem s'ohodennya»: materialy Mizhn. konf. Kam'yanets'-Podil's'k, 2012. S. 63-64. (in Ukrainian).

5. Ponomarenko S. P., Hrytsaenko Z. M., Tsygankova V. A. Increase of Plant Resistance to Diseases, Pests and Stresses with New Biostimulants. Proceedings of the I st world congress on the USE of Biostimulants in Agriculture. Eds.: S. Saa Silva [et al.]. Acta Horticulturae 1009, 2013. P. 225-234. (in English)

6. Hryhoryuk I. P. Reaktsiya roslyn na vodnyy i temperaturnyy stresy ta sposoby yikh rehulyatsiyi: avtoref. dys. ...kand. s-h nauk: 03.00.12. Kyyiv, 1996. 20 s. (in Ukrainian).

7. Hospodarenko H. M. Ahrokhimiya. Uman': VIZAVI, 2014. 400 s. (in Ukrainian).

8. Shulyak Y. V., Hrushova E. Y., Semenchenko A. M. Reolohycheskye svoystva vodnykh rastvorov polyétylenhlykoley razlychnoy molekulyarnoy massy. Zhurnal fyzycheskoy khymyy. 2011. T. 85, № 3. S. 485-488. (in Russian).

9. Kondratenko E. P., Sukhykh A. S., Verbytskaya N. V., Soboleva O. M. Byostymulyruyushchye y fyzykokhymycheskye svoystva humata natryya. Khymyya rastytel'noho syr'ya. 2016. № 3. Rezhym dostupa: jornal.asu.ru/ index.php/cw/article/view/1185 (in Russian).

\section{S. A. Pryplavko, V. M. Gaviy}

Nizhyn Mykola Gogol State University, Ukraine

\section{COMPARATIVE EFFECT OF GROWTH REGULATORS OF AZOTOFIT, AMBER ACID AND VIMPEL ON THE DYNAMICS OF GROWTH AND PRODUCTIVITY OF WINTER WHEAT VARIETIES OF YUVIVATA}

Scientific research suggests that winter wheat cultivation technologies can be regulated by plant growth regulators. These substances have a complex effect on growth and development and facilitate plant growth and crop capacity.

Three-year field studies were carried out using plant growth regulators of Azotophyte, Amber acid and Vympel to determine the dynamics of plant growth rates and their productivity. This made it possible to observe the influence of growth regulators before sewing and to establish their effectiveness at all stages of plant development. Seeds of winter wheat of the variety Jubiwata were treated with solutions of the substances under analysis. The experimental area was $40 \mathrm{~m}^{2}$.

The study demonstrated that the growth regulators do not influence the field germination rate of plants, but the percentage of germination was quite high in both control and experimental variants. 
As for the rates of plant height and root length, the first measurement of the average height of winter wheat plants in autumn demonstrated that Vympel was the most efficient. Its indicators exceeded the control variant by $3.4 \%$. After the second measurement, the plant height increased in all variants. The fourth spring measurement showed that the most powerful was the effect by Amber acid. This compound significantly inhibited plant growth compared to other growth regulators and controls.

The investigated plant growth regulators have a positive influence on the processes of root development of winter wheat plants in both autumn and spring time. This feature will provide a better nutrition of the plants.

The weight of the dry matter after the first weighing was greater in the control and the variant treated with Nitrogen. The fourth weighing showed that the best effect on the dry matter mass was found by Azotophyte, which contributed to the increase of this indicator twice as much compared to the control. Amber acid, when used for pre-sowing seed treatment, exceeded the control value by 1.8 times.

Stronger effect on the percentage of dry matter in the plant sample was found only by Vympel, under the influence of which this indicator was greater by 9 units compared to the control.

The use of synthetic growth regulators significantly increases the productivity of winter wheat, namely the length of the complex ear, the number of grains and the weight of the compound ear.

Thus, research has shown that plant growth regulators Azotophit, Amber acid and Vympel facilitate the growth and productivity of winter wheat plants of the Juvivat variety. Winter wheat crops can be treated with these substances before sowing. Determining the highest efficiency of each individual regulator, as well as the possibility of combining them to improve plant growth processes, requires further research.

Key words: plant growth regulators, winter wheat, seed germination, plant height, root length, wet weight, dry matter weight, growth, productivity.

Надійшла 27.05.2019.

УДК [581.1:582.926.2]:661.162.65

doi:10.25128/2078-2357.19.2.16

\section{В. В. РОГАЧ}

Вінницький державний педагогічний університет імені М. Коцюбинського

вул. Острозького, 32, Вінниця, 21000

e-mail: rogachv@ukr.net

\section{ДИНАМІКА НАКОПИЧЕННЯ І ПЕРЕРОЗПОДІЛУ РІЗНИХ ФОРМ ВУГЛЕВОДІВ В ОРГАНАХ РОСЛИН БАКЛАЖАНІВ ЗА ДІЇ СТИМУЛЯТОРІВ РОСТУ}

Показано, що обробка рослин баклажанів сорту Алмаз стимуляторами росту 1-НОК, ГК 3 та 6-БАП впливала на ростові процеси та кількісні показники листкового апарату. Встановлено, що ГК з збільшувала висоту рослин у середньому на 16,3\%. Усі препарати збілышували кількість листків на рослині, масу їх сирої речовини та площу листкової поверхні. Найсуттєвіше на ці показники впливала ГК. Встановлено, що протягом вегетаційного періоду відбувався відтік цукрів, переважно за рахунок редукуючих форм, від вегетативних органів до плодів як у досліді, так і у контролі. Досліджено, що вміст крохмалю зростав у корінні впродовж вегетації і у плодах у першій ії половині та знижувався в стеблах і листках. Стимулятори росту сприяли накопиченню асимілятів у вегетативних органах у першій половині вегетаційного періоду та посилювали їх відтік до плодів у другій половині вегетації. Усі препарати посилювали накопичення цукрів та крохмалю у плодах протягом 